\section{Induction of Oral Tolerance in a Case of Severe Allergy to Coconut}

Hernández-Santana GL ${ }^{1}$, Rodríguez-Plata $E^{1}$, GonzálezColino $\mathrm{CE}^{1}$, Martínez-Tadeo $\mathrm{JA}^{1}$, Bartolomé B ${ }^{2}$, GarcíaRobaina JC ${ }^{1}$, Pérez-Rodríguez $\mathrm{E}^{2}$

${ }^{1}$ Allergy Department, Hospital Universitario La Candelaria, Santa Cruz de Tenerife, Spain

${ }^{2}$ Spain Research and Development Department, Roxall, Bilbao, Spain

J Investig Allergol Clin Immunol 2019; Vol. 29(5): 380-381 doi: 10.18176/jiaci.0405

Key words: Oral tolerance induction. Allergy. Coconut.

Palabras clave: Inducción a la tolerancia oral. Alergia. Coco.

Food allergy has increased in frequency in the last 2-3 decades. Some studies report a prevalence of up to $10 \%$ [1] depending on the study population (age range, dietary habits, allergen exposure, geographic location) and on the evaluation method used. In addition, more globalized dietary habits mean that it is increasingly frequent to find patients sensitized to allergens that are not part of traditional Western cuisine, such as coconut.

Several cases of coconut allergy have been reported. Most were systemic reactions and anaphylaxis [2-7]. We present the case of a patient who underwent oral desensitization to treat coconut allergy.

A 47-year-old Thai woman living in Tenerife (Canary Islands, Spain) was assessed at our unit for suspected coconut allergy. She had a previous history of severe allergic rhinoconjunctivitis and sensitization to house dust mite that were treated with specific immunotherapy, to which she responded well. The patient reported her first coconut allergy episode 4 years earlier. She presented with dysphonia, dyspnea, and palmoplantar pruritus immediately after eating grated coconut and subsequently reduced her intake of coconut, albeit not entirely. She occasionally experienced oropharyngeal pruritus after eating small amounts of coconut-containing foods, until she experienced a second episode of anaphylaxis with coconut milk curry and was referred to our unit.

Skin tests were positive for commercial coconut extract $(8 \mathrm{~mm})$, Aroy-D coconut milk ( $8 \mathrm{~mm})$, Dunn coconut milk $(7 \mathrm{~mm})$, and dehydrated coconut $(8 \mathrm{~mm}$ ) with a 4-mm histamine-induced wheal.

Coconut-specific IgE measured using the ImmunoCAP System (Thermo Fisher) was $17.7 \mathrm{kUA} / \mathrm{L}$.

Oral challenge with coconut milk Aroy-D was not performed owing to positive results in the rub test, namely, palmoplantar and oral pruritus and dysphonia that required treatment with adrenaline.

SDS-PAGE immunoblotting with coconut pulp extract and coconut milk extract was performed according to Laemli [8]. IgEbinding proteins of approximately $70 \mathrm{kDa}, 66 \mathrm{kDa}, 43 / 40 \mathrm{kDa}$, $26.5 \mathrm{kDa}, 22 \mathrm{kDa}$, and $17 \mathrm{kDa}$ were detected in coconut pulp extract, and bands of $45 \mathrm{kDa}, 40 \mathrm{kDa}, 37 \mathrm{kDa}, 26 \mathrm{kDa}, 24 \mathrm{kDa}$, and $20.5 \mathrm{kDa}$ were revealed in coconut milk extract.

Table. Protocol, Adverse Reactions, and Treatment

\begin{tabular}{|c|c|c|c|c|c|}
\hline First Phase & Dilution $^{\mathrm{a}}$ & Dose, $\mathrm{mL}$ & Amount of Protein, $g$ & Reaction & Treatment \\
\hline \multirow[t]{5}{*}{ Day 1} & $1 / 100$ & 1 & 0.00016 & No & \\
\hline & $1 / 100$ & 2 & 0.00032 & No & \\
\hline & $1 / 100$ & 4 & 0.00064 & No & \\
\hline & $1 / 100$ & 8 & 0.00128 & No & \\
\hline & $1 / 10$ & 1.6 & 0.00256 & No & \\
\hline \multirow[t]{5}{*}{ Day 2} & $1 / 10$ & 1.6 & 0.00256 & Pharyngeal pruritus & None \\
\hline & $1 / 10$ & 3.2 & 0.00512 & No & \\
\hline & $1 / 10$ & 6 & 0.0096 & No & \\
\hline & $1 / 1$ & 1.2 & 0.0192 & No & \\
\hline & $1 / 1$ & 2.5 & 0.04 & Pharyngeal pruritus & None \\
\hline \multirow[t]{2}{*}{ Day 3} & $1 / 1$ & 2.5 & 0.04 & No & \\
\hline & $1 / 1$ & 7.5 & 0.12 & Pharyngeal pruritus & Desloratadine $5 \mathrm{mg}$ \\
\hline Day 4 & $1 / 1$ & 7.5 & 0.12 & No & \\
\hline Day 5 & $1 / 1$ & 10 & 0.16 & No & \\
\hline Day 6 & $1 / 1$ & 15 & 0.24 & No & \\
\hline Second Phase $^{\mathrm{b}}$ & & Dose, $\mathrm{mL}$ & Amount of Protein, $g$ & Reaction & Treatment \\
\hline Day 7 & & 2 & 0.136 & No & \\
\hline Day 8 & & 4 & 0.272 & No & \\
\hline Day 9 & & 6 & 0.4 & No & \\
\hline
\end{tabular}

${ }^{a}$ Dilution of coconut milk (Aroy-D) (60\% coconut in water).

${ }^{\mathrm{b}}$ Grated coconut (Hacendado). 
The patient was diagnosed with coconut allergy and prescribed a strict avoidance diet and autoinjectable adrenaline. Nevertheless, she presented with a new episode of anaphylaxis after inadvertent contact with coconut and required adrenaline and emergency care.

As she went to Thailand every year and spent some months there, avoiding coconut was very difficult for her. In Thailand, coconut is a ubiquitous allergen that is found in sauces, soups, desserts, and bakery. Therefore, we proposed desensitization.

The protocol and adverse reactions and management are summarized in the Table. For the first phase, we used commercial coconut milk Aroy-D ( $60 \%$ coconut in water) administered with dose increases every 24 hours. The second phase was performed with increasing doses of grated coconut (Hacendado) at 48-hour intervals, with maintenance of the dose reached safely at home, until a dose of $6 \mathrm{~g}$ was reached. No reactions appeared during this phase. A maintenance dose of $6 \mathrm{~g}$ of grated coconut $(0.4 \mathrm{~g}$ of protein) was prescribed 3-4 times per week. We did not increase the dose in order to avoid excess fat intake.

Today, 2 years after finishing the tolerance induction procedure, the patient maintains a regular intake of $6 \mathrm{~g}$ of grated coconut 3-4 times per week and follows an open diet, thus enabling the intake of any food with coconut as an ingredient, but not coconut itself. She has not presented new reactions. In a recent assessment, specific IgE levels to coconut had decreased to $1.98 \mathrm{kU}_{\mathrm{A}} / \mathrm{L}$.

Coconut is a tropical fruit obtained from the palm tree Cocos mucifera, which belongs to the Arecaceae family and is also known as tree nut. Coconut and products obtained from it are widely used in the food industry, as well as in body care products and medicines. Asian countries are leading consumers and exporters.

Coconut is an oval fruit that measures about $20-30 \mathrm{~cm}$ and weighs around $2.5 \mathrm{~kg}$. It consists of a thick outer shell (exosperm), a thick intermediate layer (mesocarp), and a hard inner layer (endocarp) to which the pulp (endosperm) is attached. The endosperm is the edible part of this white and aromatic fruit. The internal space houses the coconut water.

The endosperm contains a high percentage of globulins and a smaller percentage of albumins. The 2 globulins described as food allergens to date are $7 \mathrm{~S}(\operatorname{Coc} \mathrm{n} 2)$ and $11 \mathrm{~S}(\operatorname{Coc} \mathrm{n} 4)$, also known as cocosin [8].

Owing to sensitization to these proteins, cases of crossreactivity have been reported between coconut, walnuts, hazelnuts, and lentils [2,4,5]. Monosensitization to coconut has also been reported [3].

In the present case, allergenic proteins were not identified, although taking into account the molecular weights of the detected bands, some could correspond to subunits of $7 \mathrm{~S}$ globulin (156-kDa, 24-kDa, 22-kDa, and 16-kDa). Protein sequencing may have helped to identify the culprit allergens.

At present, avoidance is the recommended treatment for coconut allergy. Such a measure could considerably impact quality of life in some cultures owing to widespread consumption, with the consequent risk of accidental contact. Oral tolerance has been successfully induced to treat food allergy, mainly to milk, egg, and peanut. For other foods, there are only single case reports. To our knowledge, this is the first report of desensitization to coconut. As sensitization profiles vary from patient to patient, we do not know whether patients sensitized to proteins such as cocosin would respond in the same way. Data on desensitization to milk and egg suggest that high titers of specific IgE against casein and ovomucoid correlate with a poorer outcome of desensitization [9]. A similar phenomenon may occur with coconut and other foods. Nevertheless, we think that desensitization should always be taken into consideration when a patient presents severe allergy to a food that is widely present in his or her environment.

Funding

The authors declare that no funding was received for the present study.

\section{Conflicts of Interest}

The authors declare that they have no conflicts of interest.

\section{References}

1. Sicherer SH, Sampson HA. Food allergy: A review and update on epidemiology, pathogenesis, diagnosis, prevention, and management. J Allergy Clin Immunol. 2018;141(1):41-58.

2. Teuber SS, Rich Peterson W. Systemic allergic reaction to coconut (Cocos nucifera) in 2 subjects with hypersensitivity to tree nut and demonstration of cross-reactivity to leguminlike seed storage proteins: new coconut and walnut food allergens. J Allergy Clin Immunol. 1999;103:1180-5.

3. Tella R, Gaig P, Lombardero M, Paniagua MJ, Garcia-Ortega $P_{,}$ Richart C. A case of coconut allergy. Allergy. 2003;58:825-6.

4. Nguyen SA, More DR, Wishman BA, Hagan LL. Cross reactivity between coconut and hazelnut proteins in a patient with coconut anaphylaxis. Ann Allergy Asthma Immunol. 2004;92:281-4.

5. Manso L, Pastor C, Pérez-Gordo M, Cases B, Sastre J, Cuesta Herranz J. Cross-reactivity between coconut and lentil related to a 75 globulin and an 11S globulin. Allergy. 2010;65:1487-8.

6. Michavila-Gomez A, Amat-Bou M, Gonzalez-Cortés MV, Segura-Navas L, Moreno-Palanques MA, Bartolomé B. Coconut anaphylaxis: Case report and review. Allergo Immunopathol (Madr). 2015 Mar-Apr;43(2):219-20.

7. Garcia RN, Arocena RV, Laurena AC, Tecson-Mendoza EM. $11 \mathrm{~S}$ and 75 globulins of coconut (Cocos nucifera L.): purification and characterization. J Agric Food Chem. 2005;53:1734-9 .

8. He, F. (2011). Laemmli-SDS-PAGE. Bio-protocol Bio101: e80. DOI: 10.21769/BioProtoc.80.

9. Martorell A, Alonso E, Echeverría L, Escudero C, García-Rodríguez R, Blasco C, et al. Oral immunotherapy for food allergy: A Spanish guideline. Egg and milk immunotherapy Spanish guide (ITEMS GUIDE). Part 2: Maintenance phase of cow milk (CM) and egg oral immunotherapy (OIT), special treatment dosing schedules Models of dosing schedules of OIT with CM and EGG. Allergol Immunopathol (Madr). 2017 Sep-Oct;45(5):508-18.

Manuscript received January 29, 2019; accepted for publication April 23, 2019.

Guacimara Lucía Hernández-Santana Allergy Department Hospital Universitario La Candelaria Carretera del Rosario s/n 38010 Santa Cruz de Tenerife (Canary Islands) Spain E-mail: guacim1@hotmail.com 